\title{
AMBIENTE DA PRÁTICA DA ENFERMAGEM E OS RESULTADOS COM PACIENTES, PROFISSIONAIS E INSTITUIÇÕES
}

\begin{abstract}
Thelen Daiana Mendonça Ferreira Formada em enfermagem e mestranda na Faculdade de Enfemagem da Universidade Estadual de Campinas.

thelendaiana@yahoo.com.br
\end{abstract}

INTRODUÇÃO: O ambiente da prática é definido como um conjunto de características organizacionais que facilitam ou dificultam o desenvolvimento das atividades da enfermagem. OBJETIVOS: classificar o ambiente da prática e avaliar sua relação com a percepção do clima de segurança, qualidade do cuidado, nível de exaustão emocional, satisfação profissional e intenção de deixar o emprego no próximo ano. MÉTODO: Estudo transversal, correlacional, com abordagem quantitativa, realizado em um hospital particular, de referência para atendimento de alta complexidade do interior de São Paulo. Amostra composta por profissionais de enfermagem que prestavam assistência direta aos pacientes e trabalhavam na unidade por um período igual ou superior a três meses. Instrumentos para coleta de dados: versão brasileira da PES; subescalas clima de segurança e satisfação profissional do SAQ - Short Form; exaustão emocional do Inventário de Burnout de Maslach; uma questão, na ficha de caracterização, para avaliar a percepção da qualidade da assistência oferecida ao paciente no último turno e a intenção do profissional em deixar o emprego no próximo ano. Os dados foram tabulados no programa Microsoft Excel for Windows ${ }^{\circledR}$ e para correlacionar as variáveis foi utilizado o coeficiente de correlação de Spearman, por meio do software SPSS, versão 24. O estudo foi aprovado pelo CEP (Parecer oㅜ 2.331.210). RESULTADOS: participaram da pesquisa 420 profissionais. Quanto à avaliação do ambiente, foi calculada a média das respostas nas cinco subescalas e foram obtidos valores acima de 2,5 em todas. Na avaliação da relação dessas cinco subescalas com o clima de segurança, qualidade da assistência prestada ao paciente, exaustão emocional, satisfação profissional e a intenção de deixar o emprego foram obtidas correlações significantes, $p<0,05$. CONCLUSÃO: 0 ambiente hospitalar foi classificado como favorável à prática profissional da enfermagem. Houve correlação positiva das características do ambiente com a percepção do clima de segurança, qualidade da assistência e satisfação profissional e correlação 
negativa com a exaustão emocional e a intenção de deixar o emprego, demonstrando que investimentos no ambiente onde a enfermagem desenvolve suas atividades contribuem para melhores resultados para os pacientes, profissionais e instituições.

Palavras-chave: Ambiente de Instituições de Saúde. Esgotamento Profissional. Satisfação no Emprego. 